\title{
Ćwiczenia fizyczne jako czynnik zapobiegający nowotworom i poprawiający rokowanie: dobrze udokumentowana czy niepotwierdzona metoda?
}

\author{
Aleksandra Łacko
}

Wyniki badań obserwacyjnych wskazują, że styl życia — w tym dieta i aktywność fizyczna — wpływa na ryzyko zachorowania na szereg nowotworów oraz na rokowanie. Chociaż większość danych dotyczy związku pomiędzy otyłością a nowotworami, dostępne dowody naukowe świadczą o tym, że aktywność fizyczna może być samodzielnym czynnikiem ryzyka i czynnikiem rokowniczym. Ponieważ dowody te pochodzą przede wszystkim z badań obserwacyjnych i badań interwencyjnych oceniających wpływ aktywności fizycznej na wskaźniki metaboliczne, hormonalne i zapalne, które mogą mieć wpływ na rozwój nowotworów — są obarczone ryzykiem błędów. Aby uznać, że aktywność fizyczna jest dobrze udokumentowaną metodą zmniejszającą ryzyko zachorowania i poprawiającą rokowanie, konieczne są badania z randomizacją, których punktem końcowym będą parametry przeżycia związane z nowotworem. W świetle braku dowodów o odpowiedniej wiarygodności taki wniosek nie jest uzasadniony.

\section{Is there a sufficient evidence to confirm that physical activity decreases cancer risk and improves outcomes?}

Epidemiological data suggest that life style, including diet and physical activity — factors determining body mass, is associated with an increased risk of several cancers and with poor outcomes. Although most studies focus on obesity, there is also evidence that decreased physical activity alone may be a risk factor of cancer and predictor of poor prognosis. However, available data is limited to observational studies and few randomized trials assessing the impact of physical activity on endocrine, metabolic and infammatory biomarkers, which may be associated with cancer risk and outcomes. Observed association between physical activity and cancer could be biased and/or confounded. Data from randomized trials, which have cancer outcomes as primary end points is needed to conclude that increased physical activity is well documented method of cancer prevention and improves prognosis. With the lack of level one evidence such conclusion is not justified.

NOWOTWORY J Oncol 2016; 66, 3: 254-257

Słowa kluczowe: nowotwory, aktywność fizyczna, epidemiologia, rokowania, otyłość, nadwaga

Key words: cancer, physical activity, epidemiology, prognosis, obesity, overweight

\section{Wstęp}

Badania obserwacyjne wskazują, że czynniki związane ze stylem życia: niepalenie tytoniu, zbilansowana dieta, ograniczone spożycie alkoholu i aktywność fizyczna zmniejszają ryzyko zachorowania na nowotwory i wydłużają czas przeżycia [1]. Otyłość determinowana przez niewłaściwą dietę i niedostateczną aktywność fizyczną jest jednym z takich czynników. Liczne dane epidemiologiczne potwierdzają związek pomiędzy nadmierną masą ciała a zwiększoną częstością wielu nowotworów, a także wpływ otyłości na rokowanie u chorych na niektóre nowotwory, wśród nich — raka piersi i raka jelita grubego, a prawdopodobnie także 
raka trzonu macicy, prostaty i raka płuca. Jednak wyniki badań pozostają niejednoznaczne, a mechanizm, poprzez który masa ciała i aktywność fizyczna mogą wpływać na karcynogenezę, wciążjest nie w pełni poznany. Przykładem tego są dane dotyczące raka piersi. W metaanalizach badań stwierdzono, że u chorych otyłych w porównaniu z kobietami z prawidłową masą ciała ryzyko nawrotu i zgonu jest większe o około $30 \%[2,3]$. Natomiast określenie grupy chorych, u których otyłość skraca przeżycie, budzi wątpliwości. W dużej metaanalizie przeprowadzonej przez The Early Breast Cancer Trialists' Collaborative Group wykazano, że nadmierna masa ciała związana jest z gorszym rokowaniem jedynie u chorych na raka piersi z ekspresją receptorów hormonalnych, zwłaszcza przed menopauzą [4]. W wielu innych retrospektywnych analizach i badaniach potwierdzono związek pomiędzy otyłością a luminalnym rakiem piersi niezależnie od menopauzy [5]. Istnieją jednak doniesienia wskazujące na to, że wzrost masy ciała zwiększa ryzyko zachorowania na raka piersi bez ekspresji receptorów hormonalnych i HER2 (receptor ludzkiego naskórkowego czynnika wzrostu 2), co może wskazywać na możliwy nieodwracalny wpływ otyłości na proces nowotworzenia [6]. Samo stwierdzenie związku pomiędzy otyłością, aktywnością fizyczną i dietą a ryzykiem zachorowania i rokowaniem nie jest wystarczające. Konieczne jest wyjaśnienie, czy jest to związek przyczynowo-skutkowy i czy zmiana złych nawyków może mieć działanie protekcyjne, a następnie potwierdzenie tego w dużych, właściwie zaprojektowanych badaniach z randomizacją.

\section{Aktywność fizyczna a ryzyko zachorowania na nowotwory}

Chociaż większość danych wskazuje na otyłość jako czynnik ryzyka zachorowania i czynnik złego rokowania, dowody naukowe odnoszą się także do samej aktywności fizycznej. W badaniach obserwacyjnych stwierdzono, że przynajmniej średnia aktywność zmniejsza ryzyko zachorowania na raka jelita grubego o około 40-50\%, a raka piersi o 30-40\%. Wpływ regularnego wysiłku fizycznego na zachorowania na raka gruczołu krokowego, raka płuca i raka trzonu macicy określany jest jako prawdopodobny lub możliwy, natomiast na inne nowotwory (raka jądra, trzustki, tarczycy, jajnika) — nieznany. We wszystkich analizach istnieje jednak przynajmniej trend, wskazujący na mniejszą częstość występowania różnych nowotworów u osób aktywnych [7].

\section{Wpływ aktywności fizycznej na rokowanie u chorych na nowotwory}

Podobnie liczne badania obserwacyjne, prowadzone przede wszystkim u chorych leczonych radykalnie, wskazują na lepsze rokowanie u chorych prowadzących aktywny tryb życia [8]. W wielu doniesieniach stwierdzono także związek pomiędzy poziomem aktywności fizycznej a ryzykiem nawrotu [8,9]. Ponieważ jednak większość danych pochodzi z analiz retrospektywnych, ich wartość naukowa jest ograniczona. Zastrzeżenia budzi także zróżnicowanie projektów badań, na przykład w odniesieniu do czasu, w którym przeprowadzono ocenę aktywności fizycznej (przed leczeniem, bezpośrednio po leczeniu, po latach od zakończenia leczenia), oraz wybór punktów końcowych. Jeśli punktem końcowym jest umieralność z wszystkich przyczyn zamiast umieralności specyficznie związanej z nowotworem, można przypuszczać, że regularne ćwiczenia poprawiające ogólny stan zdrowia wydłużają czas przeżycia niezależnie od choroby nowotworowej. Także wyniki badań klinicznych i metaanalizy należy interpretować z pewną ostrożnością, ponieważ populacja chorych w badaniach różni się od leczonych w codziennej praktyce klinicznej. Zwykle są to chorzy młodsi, bez istotnych chorób towarzyszących, a odsetek osób otyłych jest w nich mniejszy. Wpływ na wyniki może mieć również leczenie przeciwnowotworowe. Chorzy uczestniczący w badaniach otrzymują należne dawki leków, ich zmniejszenie musi być uzasadnione i podyktowane sztywnymi założeniami protokołów. Natomiast liczne doniesienia wskazują, że w praktyce u chorych otyłych dawki leków cytotoksycznych są obniżane, czego konsekwencją jest mniejsza intensywność leczenia [10].

\section{Randomizowane badania interwencyjne}

Pośrednich dowodów na wpływ stylu życia na ryzyko zachorowania i rokowanie dostarczają badania interwencyjne, w których parametrami oceny są wskaźniki metaboliczne, zapalne i endokrynne, które mogą mieć znaczenie w procesie karcynogenezy. Należą do nich czynniki hormonalne (estron, estradiol, testosteron, dehydroandrostenodion, globulina wiążąca hormony płciowe [SBGH - sex hormone binding globuline]), metaboliczne (stężenie insuliny, insulinopodobnego czynnika wzrostu [IGF-1-insulin-like growth factor 1], glikemia, adyponektyna) i szereg innych, np. interleukina-6, białko C-reaktywne (CRP).

$W$ badaniach randomizowanych oceniających wpływ różnych interwencji (dieta, aktywność fizyczna, dieta i aktywność fizyczna) stwierdzono, że zmiana sposobu odżywiania oraz zwiększenie aktywności korzystnie wpływa na szereg wskaźników zarówno u osób zdrowych, jaku chorych [11-13]. Jednak ocena biomarkerów może nie odzwierciedlać działania przeciwnowotworowego interwencji. Prawdopodobieństwo, że umiarkowane zmiany stężenia wskaźników istotnie wpływają na przebieg nowotworów, jest niewielkie. Ponadto badania prowadzone wśród chorych są narażone na ryzyko błędu z powodu innych czynników ryzyka nawrotu i wpływu przebytego leczenia; ekspozycja na interwencje jest trudna do zmierzenia, publikacje zaś są wyselekcjonowane. Pomimo tych zastrzeżeń ważnym wnioskiem z badań interwencyjnych jest stwierdzenie, że zmiana stylu życia i nawyków jest trudna, ale możliwa, choć w ograniczonym 
stopniu. Spadek masy ciała, jeden z istotnych parametrów oceny skuteczności interwencji, w większości badań wynosi około 5\%-7\%, rzadko przekraczając 10\%. Kolejną, dość oczywistą obserwacją jest potwierdzenie innych korzyści ze zwiększenia aktywności i zmniejszenia masy ciała. Należy do nich poprawa sprawności fizycznej i siły mięśniowej, lepsza kontrola chorób współistniejących, np. układu sercowo-naczyniowego i cukrzycy, oraz lepsze samopoczucie [14]. $\mathrm{U}$ chorych poddanych leczeniu przeciwnowotworowemu regularne ćwiczenia skutkowały zmniejszeniem nasilenia objawów niepożądanych związanych z leczeniem oraz chorobą, np. bólu i zmęczenia. Wysiłek fizyczny tak u zdrowych, jak i chorych poprawia jakość życia, wciąż jednak brakuje wyników dużych badań z randomizacją oceniających wpływ aktywności fizycznej na rokowanie, w których punktami końcowymi byłyby wskaźniki przeżycia związane z nowotworem. Takie badania są obecnie prowadzone u chorych na raka piersi po leczeniu radykalnym (badanie STARTSupervised Trial of Areobic versus Resistance Training), oraz chorych na raka jelita grubego (CHALLENGE: The Colon Health and Life-Long Exercise Change).

\section{Charakter związku pomiędzy aktywnością fizyczną a ryzykiem zachorowania na nowotwór i rokowaniem}

Dysponując danymi dowodowymi średniej jakości, nie można wykluczyć, że związek przyczynowo-skutkowy pomiędzy aktywnością fizyczną a ryzykiem zachorowania na nowotwory jest błędem systematycznym i w rzeczywistości nie istnieje. Podobnie charakter związku pomiędzy stylem życia a rokowaniem u chorych na nowotwory nie jest jasny. Osoby prowadzące zdrowy tryb życia są bardziej zdyscyplinowane, częściej wykonują zalecone badania, w tym także profilaktyczne i przesiewowe, mają więc większą szansę na wcześniejsze rozpoznanie i radykalne leczenie. U osób otyłych rozpoznanie częściej jest opóźnione, a leczenie przeciwnowotworowe bywa mniej agresywne. Aktywność niektórych leków przeciwnowotworowych, na przykład inhibitorów aromatazy stosowanych w leczeniu hormonalnym raka piersi, jest mniejsza u chorych z nadmierną masą ciała [15]. Obserwowana tendencja do zmniejszania należnych dawek leków cytotoksycznych u osób otyłych może zmniejszać skuteczność chemioterapii [10]. Adaptacja do zdrowych nawyków związana jest zwykle z lepszą współpracą i przestrzeganiem zaleceń. Dlatego leczenie przeciwnowotworowe może być w tej grupie lepiej tolerowane, a jego wyniki są lepsze w porównaniu do chorych pozbawionych zdrowych nawyków. Jeśli zaś związek przyczynowo-skutkowy pomiędzy stylem życia (otyłością, dietą i aktywnością fizyczną) a ryzykiem zachorowania i rokowaniem istnieje, może mieć charakter odwracalny lub nieodwracalny. Tylko w sytuacji, gdy jest to związek odwracalny, zmiana stylu życia będzie miała korzystne skutki [16].

\section{Zalecenia}

Wiele towarzystw naukowych i organizacji zajmujących się zapobieganiem nowotworom i ich leczeniem, takich jak Center for Disease Control, National Cancer Institute i American Cancer Society, w swoich raportach stwierdza, że aktywnośćfizycznajest związana lub może byćzwiązanazniższym ryzykiem zachorowania na nowotwory [17-19]. Utrzymanie prawidłowej masy ciała, właściwa dieta i regularne ćwiczenia są powszechnie zalecane, a badania związku pomiędzy stylem życia a nowotworami zyskały priorytet. Zdrugiej strony w publikacjiWorld Cancer Research Fund w odniesieniu do raka piersi zaznaczono, że dowody łączące nadmierną masę ciała, poziom aktywności fizycznej i dietę z wynikami leczenia mają ograniczoną wartość, ponieważ w przeważającej części pochodzą z badań obserwacyjnych i są narażone na błędy [20]. Podobne wątpliwości odzwierciedla dyskusja podczas ostatniego spotkania ekspertów w St. Gallen, dotycząca zasad leczenia wczesnego raka piersi. Na pytanie, czy należy zalecać dietę i aktywność fizyczną, aby zmniejszyć ryzyko nawrotu, 87,5\% głosujących opowiedziało się za utratą masy ciała w przypadku nadwagi lub otyłości i unikaniem jej przyrostu, 76,7\% za zalecaniem regularnego wysiłku fizycznego, a $40 \%$ za poradnictwem dietetycznym. Natomiast w publikacji, która stanowi podsumowanie uzgodnionych zaleceń, wświetle braku ewidencji naukowej, znalazło się ostrożne sformułowanie „U chorych na raka piersi otyłość związana jest z gorszym rokowaniem" $[16,21]$.

\section{Podsumowanie}

Odpowiedź na pytanie, czy zmiana stylu życia, w tym zwiększenie aktywności fizycznej, powinna być zalecana osobom zdrowym w celu zapobiegania zachorowaniu na nowotwór, jak również chorym, aby zmniejszyć ryzyko nawrotu choroby — nie jest zatem prosta. Nie ma wątpliwości, że należy promować zdrowy tryb życia, utrzymanie prawidłowej masy ciała i przynajmniej umiarkowany, za to regularny wysiłek fizyczny, ponieważ są to działania, które poprawiają ogólny stan zdrowia i jakość życia, zmniejszają umieralność z wszystkich przyczyn, a u chorych sprawiają, że lepiej tolerują leczenie przeciwnowotworowe. Nie są to jednak metody dobrze udokumentowane. Czy rzeczywiście zmiana stylu życia, w tym zwiększenie aktywności fizycznej, zmniejsza ryzyko zachorowania na nowotwory i poprawia rokowanie, wciąż nie wiemy.

\section{Konflikt interesów: nie zgłoszono}

\section{Dr n. med. Aleksandra Łacko}

Katedra Onkologii Uniwersytetu Medycznego im. Piastów Śląskich we Wrocławiu

Uniwersytecki Szpital Kliniczny

ul. Borowska 213, 50-556 Wrocław

tel. 717331021

e-mail:olalacko@wp.pl

Otrzymano i przyjęto do druku: 23 maja 2016 r. 
Na podstawie wystąpienia podczas IV Konferencji Naukowej czasopisma Nowotwory „Debaty onkologiczne”, 8-9 kwietnia 2016 r.

\section{Piśmiennictwo}

1. Khaw KT, Wareham N, Bingham S i wsp. Combined impact of health behaviours and mortality in men and women: the EPIC-Norfolk prospective population study. PLoS Med 2008; 5: e12.

2. Protani M, Coory M, Martin JH i wsp. Effect of obesity on survival of women with breast cancer: Systematic review and meta-analysis. Breast Cancer Res Treat 2010; 123: 627-635.

3. Chan DS, Vieira AR, Aune D i wsp. Body mass index and survival in women with breast cancer-systematic literature review and meta-analysis of 82 follow-up studies. Ann Oncol 2014; 25: 1901-1914.

4. Pan H, Gray RG. Effect of obesity in premenopausal ER+ early breast cancer: EBCTCG data on 80,000 patients in 70 trials. J Clin Oncol 2014; 32: 5s, 2014 (Suppl; abstr 503).

5. Sparano JA, Wang M, Zhao F i wsp. Obesity at diagnosis is associated with inferior outcomes in hormone receptor-positive operable breast cancer. Cancer 2012; 118: 5937-5946.

6. Pierobon M, Frankenfeld CL. Obesity as a risk factor for triple-negative breast cancers: a systematic review and meta-analysis. Breast Cancer Res Treat 2013; 137: 307-314.

7. Friedenreich Ci Orenstein M.Physical activity and cancer prevention: etiologic evidence and biological mechanisms.JNutr 2002; 132;3456-3464.

8. Ballard-Barbash R, Friedenreich CM, Courneya KS i wsp. Physical activity, biomarkers, and disease outcomes in cancer survivors: A systematic review. J Nat/ Cancer Inst 2012; 104: 815-840.

9. Wu Y, Zhang D, Kang S. Physical activity and risk of breast cancer: a meta-analysis of prospective studies. Breast Cancer Res Treat 2013; 137: 869-882.

10. Griggs JJ, Mangu PB, Anderson H i wsp. Appropriate chemotherapy dosing for obese adult patients with cancer: American Society of Clinical Oncology clinical practice guideline. J Clin Oncol 2012; 30: 1553-1561.
11. Friedenreich CM. Physical activity and breast cancer: review of the epidemiologic evidence and biologic mechanisms. Recent Results Cancer Res 2011; 188, 125-139.

12. Foster-Schubert KE, Alfano CM, Duggan CR i wsp. Effect of diet and exercise, alone or combined, on weight and body composition in overweight-to-obese postmenopausal women. Obesity (Silver Spring). 2012; 20: 1628-1638.

13. Harrigan M, Cartmel B, Loftfield E i wsp. Randomized trial comparing telephone versus in-person weight loss counseling on body composition and circulating biomarkers in women treated for breast cancer: The Lifestyle, Exercise, and Nutrition (LEAN) Study. J Clin Oncol; 2016; 34: 669-676.

14. Speck R, Corneya K, Masse L i wsp. An update of controlled physical activity trials in cancer survivors: a systematic review and meta-analysis. J Cancer Surviv 2010; 4: 87-100.

15. Pfeiler G, Königsberg R, Fesl C i wsp. Impact of body mass index on the efficacy of endocrine therapy in premenopausal patients with breast cancer: an analysis of the prospective ABCSG-12 trial. J Clin Oncol 2011: 2653-2659.

16. Goodwin P. Obesity and breast cancer outcomes: how much evidence is needed to change practice? J Clin Oncol 2016; 34: 646-648.

17. Centers for Disease Control and Prevention. Cancer Prevention and Control. http://www.cdc.gov.

18. National Cancer Institute at the National Institutes of Health. Cancer Statistics. http://www.cancer.gov.

19. American Cancer Society. Explore Research. http://www.cancer.org.

20. World Cancer Research Fund International/American Institute for Cancer Research Continuous Update Project Report Diet, nutrition, physical activity and breast cancer survivors. www.wcrf.org/sites/default/files/ Breast-Cancer-Survivors-2014-Report.pdf.

21. Coates AS, Winer EP, Goldhirsch A i wsp. Tailoring therapies-improving the management of early breast cancer: St Gallen International Expert Consensus on the Primary Therapy of Early Breast Cancer 2015. Ann Oncol 2015; 26: 1533-1546. 